удк 340.1

DOI https://doi.org/10.32837/pyuv.v0i4(39).906

\author{
I. В. Проиюк \\ orcid.org/0000-0003-0546-6187 \\ доктор юридичних наук, професор, \\ професор кафедри теорії і філософії права \\ Національного юридичного університету імені Ярослава Мудрого
}

\title{
КЛАСИФІКАЦІЯ ЗАКОНІВ: ЗАГАЛЬНОТЕОРЕТИЧНІ АСПЕКТИ
}

Постановка проблеми. У Конституції України та інших законодавчих актах поняття закону $€$ «цілісним», тобто відсутній конституційно і законодавчо закріплений поділ законів на окремі види. Певне виокремлення передбачене у проєкті Закону України «Про правотворчу діяльність», поданому на розгляд Верховної Ради України народними депутатами Р.О. Стефанчуком, Д.О. Разумковим, О.К. Кондратюк та іншими. У п. 2 ст. 9 цього проєкту вказано, що система нормативно-правових актів включає: 1) Конституцію України - Основний Закон України; 2) закони, кодекси України [1]. Такий поділ $€$ досить загальним і не повністю відповідає всім вимогам юридичної практики щодо розподілу законів на види для їх більш ефективного застосування.

Водночас у науковій літературі зазначається, що поняття закону є багатоаспектним, виокремлюють його види. Необхідно зауважити, що такий поділ існував та існує у вітчизняній і закордонній науковій юридичній літературі, а також закріплений у конституціях багатьох держав світу. Наприклад, Конституція Франції 1958 р. визначає такі види законів: конституційні, органічні, фінансові, програмні та прості [2, с. 105-135]. Конституція Іспанії 1978 р. вирізняє органічні, спеціально уповноважувальні, закони-декрети та прості закони [2, с. 297-351].

Про закон часто говорять в збірному розумінні, охоплюючи цим поняттям весь масив нормативно-правових актів. Слід зазначити, що доводиться відзначати явну недостатність розробки проблеми класифікації законів, що негативно позначається на практиці ухвалення і дії законів, на вирішенні питань про співвідношення між різними законами, законів із підзаконними актами тощо. Часткові класифікації не дають можливості охопити все різноманіття законів і визначити співвідношення одиничного, особливого та загального, яке має лежати в основі будь-якої класифікації [3, с. 11].

Аналіз останніх досліджень. Дослідженню поняття, ознак і критеріїв поділу законів на види у системі законодавчих актів присвячено велику кількість наукових праць вітчизняних та зарубіжних науковців. Відзначимо напрацювання в цій сфері Л. Андрусів, С. Бобровник, С. Бошно, М. Кельмана, М. Козюбри, О. Мурашина, М. Савенко, О. Петришина, П. Рабіновича, Ю. Тихомирова, М. Теплюка, М. Цвіка, О. Ющика. Проблемні аспекти нормативно-правових актів крізь призму юридичної техніки досліджували І. Биля-Сабадаш, В. Косович, Л. Луць, Т. Подорожна, І. Шутак та інші науковці.

Метою статті є дослідження системи законодавчих актів і визначення основних критеріїв розподілу законів на групи (види). Для цього варто вирішити такі взаємопов'язані завдання: розглянути основні критерії виокремлення деяких законів у системі законодавчих актів; проаналізувати юридичну природу, значення, силу, призначення та особливості законів і запропонувати основні підходи до їх класифікації та нормативного закріплення такої класифікації.

Виклад основного матеріалу. Поділ законів на види можна проводити за низкою критеріїв. Ці критерії залежать від типу правової сім'ї і специфіки національних правових систем [4, с. 146]. У літературі виокремлюють низку критеріїв поділу законів на види: за юридичною силою і процедурою ухвалення (конституційні та звичайні); за роллю в правовому регулюванні (первинні і вторинні); за ступенем упорядкованості (поточні і кодифіковані); за колом осіб (загальні і спеціальні); за часом дії (постійні і тимчасові) [5, с. 265-266]; за юридичною силою (конституція, конституційні закони, органічні закони, звичайні закони); за предметом галузевого регулювання (конституційні, цивільні, адміністративні тощо); за юридичною формою вираження (конституція, кодекс, основи законодавства, закон) [6, с. 221]. На нашу думку, доцільно було б виділити такі основні критерії поділу: а) питання, що регулюються законом; б) юридична сила закону; в) структурна форма закону; г) простір, у межах якого діє закон; г) термін його дії; д) спосіб розгляду і прийняття; е) цільове призначення і зміст; є) особи, на яких він поширює свою дію; ж) час набрання чинності. Безумовно, не можна вважати цей перелік вичерпним, є й інші, на нашу думку, менш важливі критерії поділу законів на види.

Під час виокремлення видів законів за низкою питань, що ними регулюються, доцільно виходити 3 того, на які основні сфери суспільного чи державного життя вони поширюють свою дію. За цим критерієм, виходячи з галузей законодавства, можна визначити закони в галузі цивільно- 
го права або цивільні, в галузі адміністративного права або адміністративні, в галузі кримінального права або кримінальні та інші закони. Як зазначається в літературі, «галузева класифікація законодавства має велике практичне значення. Саме вона здебільшого сприяє користувачеві в пошуку необхідних норм. Насправді людина шукає для своїх потреб не закон, а вирішення свого питання, вирішення життєвої ситуації. Відповідь міститься в законі про ці відносини» [3, с. 12]. Таким чином, суб'єкт права, визначившись з видом суспільних відносин, може досить швидко обрати той закон, який необхідно застосовувати у цій життєвій ситуації.

Структурна форма дозволяє розрізняти закони за ступенем узагальнення регулювання суспільних відносин і за структурним способом організації нормативного матеріалу. Керуючись цим критерієм, на нашу думку, допустимо виділяти з усієї безлічі законів прості тематичні закони та кодифіковані (основи законодавства і кодекси). Водночас слід зауважити, що за юридичною силою ці закони є рівними, що створює певні проблеми під час ïx застосування, особливо коли простий закон i кодекс регулюють одні й ті ж суспільні відносини. Як зазначає Є. Гетьман, «хотілося б наголосити на тому, що на сьогодні такий кодифікаційний акт, як кодекс, не має вищої юридичної сили, порівняно з іншими галузевими правовими актами, подібна ситуація може бути виправлена через ухвалення відповідного закону про нормативні акти» [7, с. 44]. На нашу думку, ухвалення зазначеного закону позитивно вплинуло би на юридичну практику і вирішило би багато дискусійних питань юридичної науки щодо розподілу нормативно-правових актів загалом й основного їх різновиду - законів, зокрема. Також слід зазначити, що Закон України «Про нормативні правові акти» був ухвалений Верховною Радою України 13 січня 2000 р., проте був ветований Президентом України, а отже, не набрав чинності, тож результати голосування Верховної Ради України щодо прийняття в першому та подальших читаннях проєкту Закону України про нормативно-правові акти (реєстр. № 0923) 5 квітня 2001 р. було скасовано [8]. Надалі проєкти подібних законів подавалися на розгляд парламенту України ще декілька разів, проте не були прийняті. Вважаємо, що потреба в такому законі існує. Крім того, подібні закони ухвалені в багатьох пострадянських країнах, зокрема у Білорусі в 2000 р., у Вірменії в 2018 р. тощо. Щодо співвідношення між поточним законом і кодексом, то в науковій юридичній літературі наголошується на більшій значущості, а отже, й юридичній силі кодексу (основ законодавства), порівняно з поточним законом [9, с. 13]. Проте слід погодитися 3 Є. Гетьманом, що «неможливим є надання кодексу більшої юридичної сили, порівняно з іншими законами, оскільки загальновизнаною є думка, відповідно до якої теорія кодексу нерозривно пов'язана з теорією закону» [7, с. 46]. Водночас у разі колізії між кодексом і поточним законом перевагу слід надавати кодексу як спеціальному закону стосовно загального, оскільки він регулює особливу сферу суспільних відносин і є, по суті, спеціальним законом. Кодекс - це системоутворювальний законодавчий акт, що регулює визначену сферу суспільних відносин, навколо якого формуються інші законодавчі і підзаконні акти, які є відповідною сферою законодавства.

За дією у просторі закони можна поділити на ті, що діють на території усієї держави, та ті, що діють лише на визначеній частині території. Для федеративних держав існує поділ законів на закони федерації та закони суб’єктів федерації. Таке виокремлення має надзвичайно важливе значення для федеративних держав, оскільки вказує територіальні межі дії законів, співвідношення між законами федерації загалом і законами їі суб'єктів. Між такими законами має бути органічна системна взаємопов'язаність, де за загальним правилом закони суб'єктів федерації мають відповідати законам федерації. При цьому, як зазначається в літературі, «юридична природа цих способів зв' язку не означає прямого співпідпорядкування норм законів, тому тут ми маємо справу з однопорядковими явищами. Це стан їх функціонально-юридичної узгодженості, яка виключає суперечності, несумісність і своєрідну ізольовану дію» [3, с. 15]. А отже, визначаючи, який закон слід застосовувати, слід комплексно використовувати різні способи юридичної техніки.

За терміном дії закони поділяються на постійні і тимчасові. Більшість законів діють постійно до їх скасування, ухвалення нових законів, що регулюють аналогічні суспільні відносини тощо. Проте деякі закони приймаються на певний термін, наприклад Закон «Про державний бюджет України» - на один рік. Водночас важливим є те, що час дії може встановлюватися на конкретні проміжки, зокрема з якої й по яку дату діє певний закон, а також на період існування певної соціально значущої події, явища (війни, стихійного лиха, пандемії тощо). В останньому випадку в законі визначаються не конкретні часові межі, а, власне, його дія, пов'язана з існуванням такого явища чи події. Ці закони можна визначати як надзвичайні, оскільки вони розраховані на регулювання суспільних відносин під час не сталих, а надзвичайних подій, які мають велику суспільну значущість. Такий поділ має важливе практичне значення, коли розглядаються питання про дію законів у часі, оскільки показує часові межі їх дії, а отже, полегшує їх реалізацію для суб'єктів права.

За способом розгляду й ухвалення закони поділяються на прийняті на референдумі та ті, що 
прийняті вищим представницьким органом (парламентом), в Україні - Верховною Радою України. Цей поділ має значення, виходячи з місця і ролі таких законів у системі законодавства, а також порядку їх зміни чи скасування. Абсолютна більшість законів приймається парламентом. Так, в Україні наразі всі закони прийняті виключно Верховною Радою України, на референдумі не було ухвалено жодного закону. В інших країнах світу є певна практика прийняття законів на референдумах. Наприклад, Конституція РФ у 1993 р. була ухвалена на референдумі, Конституція Білорусі в 1997 р. також була прийнята на референдумі. Можливість ухвалення законів на референдумі сьогодні передбачена Законом України «Про Всеукраїнський референдум» від 26 січня 2021 р. Так, ст. 3 цього закону в сфері законодавства визначає предметом всеукраїнського референдуму затвердження закону про внесення змін до розділів I, III, XIII Конституції України та про втрату чинності законом України або окремими його положеннями [10]. Відповідно, закони прийняті на референдумі, апріорі наділяються вищою юридичною силою, адже вони є безпосереднім проявом народовладдя, виявленням прямої волі народу. Існує думка, начебто референдум, порівняно 3 народним представництвом, має переваги, бо він дозволяє послідовно проводити в життя принцип народовладдя. Одним із родоначальників такого погляду був Ж⿱乛.-童. Руссо, який виступав за ухвалення всіх законів безпосередньо народом, базуючись на тому, що «влада законодавча належить народу і може належати тільки йому» [11, с. 87].

Проте думка про беззаперечні переваги референдуму послідовно не обгрунтована, оскільки референдум також має і значні недоліки. По-перше, навіть в тому разі, коли постановка питань на референдумі висловлена досить чітко, вона залишає тільки два варіанти відповіді: «так» чи «ні». А внести зміни або доповнення до винесеного на референдум проєкту закону, погодитись з одними його положеннями і відкинути інші виборці не можуть. По-друге, суспільна думка є лише порівняно самостійною, вона може стати жертвою маніпуляцій політиків. У суспільстві з низьким рівнем політичної і правової культури це надто небезпечно. Визнаючи це, Ж⿱乛.-Ж⿱乛⿻ Руссо вказував, що «підкупити народ не можна, але його можна обдурити» [11, с. 47]. По-третє, далеко не кожне питання законодавства може бути вирішене загальнонародним голосуванням. Для прийняття рішень зі складних питань потрібне їх спеціальне опрацювання в законодавчих і виконавчих структурах влади із залученням десятків, сотень експертів, спеціалістів із зазначених питань [12, с. 174].

Ще Ш.-Л. Монтеск'є стверджував, що народ сам по собі не може ефективно і кваліфіковано управляти державою. Для цього він повинен обирати зі свого середовища найбільш обізнаних і поважаних людей. «Велика перевага обраних представників у тому, що вони здатні обговорювати справи. Народ для цього зовсім непридатний, що й становить одну з найслабкіших сторін демократії» [13, с. 159]. Саме тому представницький орган визначає у процесі дискусії народну волю, загальний інтерес і виражає їх у відповідних законодавчих актах. Окрім наведених аргументів, слід вказати і на те, що проведення референдумів вимагає досить значних матеріальних витрат та здійснення організаційної роботи. Це робить неможливим прийняття багатьох законів у такий спосіб у більшості країн, зокрема і в Україні. Між тим не підлягає сумніву, що прийняття законів на референдумі можливе для затвердження найбільш значущих законодавчих актів усім народом, після їх детального опрацювання й узгодження гілками влади.

За цільовим призначенням і змістом можна виділити закони: інституційні, норми яких регламентують функціонування певних інституцій у суспільстві (присвячені визначенню статусу державних органів, суспільних організацій, трудових колективів тощо), регламентаційні, що регулюють відповідну сферу суспільних відносин чи їх комплекс, і проблемно-ситуаційні, котрі спрямовані на вирішення значущої соціальної мети в межах певного періоду, тощо.

Також закони можна класифікувати за колом осіб, зокрема Закон «Про статус народного депутата України», Закон «Про Президента України» та інші спеціальні або загальні закони.

Найбільш важливим критерієм поділу законів на види, на нашу думку, є їх юридична сила. Співвідношення законів за юридичною силою за їх реалізації в разі можливих колізій у конкретних життєвих ситуаціях дає змогу визначити, який законодавчий акт у цьому випадку слід застосовувати. Згідно з цим критерієм, можна виокремити такі види законів: конституції, конституційні закони, звичайні закони і закони, що затверджують інші нормативні акти [3, с. 12]. У літературі наведена думка, що, крім цих видів законів, за юридичною силою в Україні слід виокремити також органічні закони [14, с. 5]. Так, Є. Назаренко зазначає, що в Конституції України вказано на необхідність прийняття досить великої кількості органічних законів, які, залишаючись у конституційному полі і спираючись на Конституцію, мають конкретизувати основні права, свободи й обов'язки громадян у різних галузях суспільного життя, а також організацію і функціонування органів державної влади та місцевого самоврядування і відносини людини та держави на основі народовладдя [15, с. 34]. Безумовно, можна виокремлювати органічні закони, оскільки вони 
існують в США, Франції, Грузії й інших державах. Проте наразі в Україні, на думку А. Зайця, недоцільно запроваджувати органічні закони, бо така практика може призвести до ускладнення системи законодавства, виникнення внутрішніх суперечностей, приниження значення Конституції України, внести плутанину у правозастосовну діяльність [16, с. 56].

Особливе місце серед законів посідає Конституція як основний закон держави, що має найвищу юридичну силу. Тому ст. 8 Конституції України визначає, що всі закони й інші нормативно-правові акти повинні прийматися на основі Конституції України та відповідати їй. Слід зауважити, що Конституція України є не просто Основним Законом, а перебуває вище над законами.

Конституція України констатуе саме існування держави. На основі її норм утворюються i функціонують державні інститути, які уповноважені Конституцією займатися правотворчістю [17, с. 15]. Як зазначається у рішенні Конституційного Суду України від 3 жовтня 1997 р.: «Конституція України як Основний Закон держави за своєю юридичною природою є актом установчої влади, що належить народу. Установча влада стосовно так званих встановлених влад є первинною: саме в Конституції України визнано принцип поділу державної влади на законодавчу, виконавчу і судову (ч. 1 ст. 6 Конституції України) та визначено засади організації встановлених влад, зокрема законодавчої. Прийняття Конституції України Верховною Радою України означало, що в такому випадку установча влада була здійснена парламентом. Закони є актами встановленої Конституцією України законодавчої влади й актами єдиного органу законодавчої влади - Верховної Ради України. Це зумовлює їх субординацію відносно Конституції України» [18, с. 29]. Отже, Конституція $є$ не просто Основним Законом як актом законодавчої влади, а стоїть над законами і над гілками влади загалом. Проте за зовнішньою формою вона $є$ нормативно-правовим актом установчої влади, що характеризується всеосяжним характером, встановлює основні засади в усіх сферах життя суспільства.

Конституція України - це єдиний нормативно-правовий акт, через який український народ, виражаючи свою суверенну волю, засновуе основні принципи устрою суспільства та держави, визначає систему і структуру державної влади та місцевого самоврядування, механізми реалізації державно-владних повноважень, основи правового статусу особи, територіальний устрій, символіку держави й інші засади суспільного життя. Як зазначає відомий фахівець з конституційного права України О. Марцеляк: «Конституція України увібрала в себе передовий досвід розвинених демократичних країн у сфері конституціоналіз- му, гуманістичні цінності світової спільноти, чітко визначила баланс між інтересами та потребами держави, суспільства й окремої особистості. Й таким чином як правовий акт вищої юридичної сили вона виступила правовим фундаментом формування України як демократичної, правової, соціальної держави, стала політико-правовим документом програмного характеру, який спрямував українське суспільство, органи державної влади на відповідні демократичні реформи у сфері вітчизняного державотворення» $[19$, с. 79]. Конституція виступає правовим фундаментом державного і суспільного життя, основним джерелом національної правової системи. В ній знаходять висвітлення питання не тільки державного характеру, але й відносин держави та інституцій громадянського суспільства: політичних партій, профспілкових, релігійних організацій, суспільних рухів. Таким чином, для демократичної правової країни конституція $є$ основним законом не тільки держави, але й суспільства. Цінність демократичної конституції полягає насамперед у тому, що вона обмежує можливості втручання держави в сферу громадянського суспільства.

Сучасний підхід, характерний для конституцій демократичних держав, спирається на визнання того фактору, що сутність конституції демократичної держави повинна проявлятися в юридичному закріпленні узгоджених інтересів і волі всіх соціальних груп, прошарків, класів тощо, які становлять державно-організоване суспільство. По суті, конституція виступає юридично визначеним балансом інтересів усіх соціальних структур суспільства і є водночас результатом компромісу суспільства, всіх його політичних сил, а отже, й актом суспільної згоди. 3 огляду на це слід зауважити, що, безумовно, в конституції складно однаково врахувати інтереси всіх членів суспільства. Більше того, це практично неможливо. Проте було б неправильним стверджувати, що конституція виражає волю економічно панівних сил, адже, якби вона виражала волю тільки великого капіталу, навряд чи змогла б виконати своє призначення - служити інструментом громадянського миру, формулювати такі «правила гри» на політичній сцені, визначати такий устрій суспільства і влади, які більшістю народу визнаються справедливими. Конституція є відображенням балансу соціальних інтересів [20, с. 43].

Наступним після конституції видом законів за юридичною силою є конституційні закони. В літературі висловлювалися різні погляди щодо ознак цих законів. Ю. Тихомиров визначає три можливі основні ознаки таких законів: 1) закони, які офіційно в установленому порядку виокремлені в самостійну групу актів під назвою "конституційний закон»; 2) для цих законів існує особливий порядок прийняття, як правило, кваліфікаційною більшістю депутатів; 3) закони, видання яких 
прямо передбачено в конституціях [21, с. 53-54]. П. Васильченко тлумачить конституційні закони як закони, що вносять зміни та доповнення до конституції. Їх юридичною особливістю $€$ порядок прийняття та вища юридична сила. Механізм прийняття конституційних законів вирізняється жорсткою процедурою [22, с. 142]. В одному з проєктів Закону України «Про нормативні правові акти» конституційний закон визначається як поєднаний з Основним Законом нормативний акт, що приймається в установленому Конституцією порядку і з визначених нею питань або вносить зміни та доповнення до Конституції [23, с. 144]. Вважаємо, що доцільніше було б ухвалити спеціальний закон, в якому були б чітко відображені основні ознаки конституційного закону для більш узгодженої позиції щодо їх застосування, оскільки після конституції наступними за юридичною силою $є$ саме конституційні закони.

Аналізуючи наукові розробки з цього питання, можна виокремити такі основні ознаки конституційного закону: 1) конституційний закон повинен регулювати найбільш важливі суспільні відносини і прийматися 3 питань, передбачених конституцією (наприклад, Закон «Про всеукраїнський референдум», Закон «Про вибори народних депутатів України»); 2) для його прийняття, згідно 3 Конституцією, потрібна кваліфікована більшість голосів від конституційного складу парламенту, тобто дві третини; 3) юридична природа конституційного закону зумовлюється його безпосереднім зв'язком із конституцією.

У Конституції України таке поняття, як конституційний закон, відсутне, на відміну від конституцій інших держав. Так, ст. 69 Конституції Литовської Республіки визначає, що «конституційні закони Литовської Республіки приймаються, якщо за них проголосувала понад половина від загального числа членів Сейму, а зміни до них вносяться більшістю голосів не менше ніж $3 / 5$ від загального числа членів Сейму. Перелік конституційних законів встановлюється Сеймом більшістю голосів $3 / 5$ членів Сейму» [24, с. 65]. Ст. 72 Конституції Республіки Молдова визначає такі види законів: конституційні, органічні й ординарні $[24$, с. 210$]$. Аналогічні положення є у багатьох конституціях. Проте аналіз Конституції України, зокрема ст. 20, 155, 156, дає підстави вважати, що парламент України приймає як звичайні закони, так i ті, що хоч і не називаються «конституційними», але, по суті, $є$ ними.

Ст. 20 Конституції України передбачає, що Великий Державний Герб України та слова Державного Гімну України затверджуються законами більшістю не менше ніж дві третини голосів від конституційного складу Верховної Ради України. Отже, в цьому разі мова йде про конституційні закони. Для визнання закону конституційним досить таких ознак: зазначення закону в Конституції України й ускладненого порядку прийняття або внесення цим законом змін до Конституції України. Конституційні закони, на нашу думку, мають вищу юридичну силу щодо інших законів. Хоча є й інший погляд. Так, В. Шаповал зауважує, що «немає жодних підстав говорити про якусь їх відмінність від звичайних, поточних законів» [17, с. 21]. Але в такому разі немає жодного сенсу вирізняти цю групу законів 3-поміж інших, крім того, якщо закон вносить зміни до конституції, то в будь-якому разі він має вищу юридичну силу в системі законодавства.

Найбільшу групу законів становлять звичайні закони. Закон (звичайний) - це нормативний акт, який приймається на основі Конституції України, містить первісні правові норми з основних питань у певних сферах суспільних відносин, становить основу системи права і має вищу юридичну силу щодо підзаконних нормативних актів.

Висновки. Таким чином, щоб закон займав належне місце в системі нормативно-правових актів, встановлював справедливе регулювання суспільних відносин, він, перш за все, має бути правовим. Іерархія законів повинна бути однозначною і повною, щоб забезпечувати чітко визначену роль, peгулятивні та охоронні цінності кожного конкретного законодавчого акта. Тож доцільно нарешті в Україні розробити та ухвалити Закон «Про нормативно-правові акти», взявши за основу ті проєкти, що подавалися до Верховної Ради України, та інші, розроблені науковцями ще понад 20 років тому. В такому спеціальному законі має бути визначена класифікація законодавчих актів із встановленням ï співвідношення за значущістю та юридичною силою для ефективного застосування під час регулювання суспільних відносин із формуванням єдиної системи законодавства. Це повинно призвести до формування ціннісного характеру всієї системи законів, які мають створювати нормативну основу для побудови в Україні демократичної, правової, соціальної держави. Класифікація законів не може бути незмінною, оскільки вона залежить від розвитку держави, юридичної науки, рівня розвитку політичної і правової культури суспільства тощо. Тому система законодавства завжди перебуває в процесі постійного розвитку й удосконалення. Отже, критеpiї поділу законів на види в науці можуть бути різні, певні критерії поділу на види законів зникають, інші - з'являються, постійно оновлюється і формується відповідна система законодавчих актів.

\section{Jimepamypa}

1. Про правотворчу діяльність : проєкт Закону України від 25 червня 2021 р. № 5707 / Верховна Рада України. Законотворчість. URL: http://w1.c1.rada.gov.ua/ pls/zweb2/webproc4_1?pf3511=72355 (дата звернення: 29.09.2021).

2. Конституция Франции. Конституция Испании. Конституции зарубежных государств : учеб. пособие / сост., пер. В. Маклаков. 4-е изд., перераб. и доп. Москва : Волтерс Клувер, 2003. 593 с. 
3. Тихомиров Ю., Бошно С. Теоретические основы классификации законов. Право и совреленные госу дарства. 2018. № 2/3. С. 9-19.

4. Велика українська юридична енциклопедія: у 20 т. Харків : Право, 2017. Т. 3: Загальна теорія права. $952 \mathrm{c}$.

5. Загальна теорія права : підручник / за ред. О. Петришина. Харків : Право, 2020.568 с.

6. Луць Л. Загальна теорія держави і права : навч.-метод. посібник. Київ : Атіка, 2013. 412 с.

7. Гетьман Є. Кодекс як особливий вид закону. Вісник Академї правових наук України. Харків, 2011. № 1. C. 42-50.

8. Про Закон України «Про нормативно-правові акти» : Постанова Верховної Ради України від 5 квітня 2001 р. № 2369-III / Верховна Рада України. Законодавство України. URL: https://zakon.rada.gov.ua/ laws/show/2369-III\#Text (дата звернення: 29.09.2021).

9. Пархоменко Н. Кодифікація законодавства України на сучасному етапі. Проблели кодифікацї̈ за конодавства України : матеріали наук.-практ. конф. Київ, 2003. С. 12-16.

10. Про всеукраїнський референдум : Закон України від 26 січня 2021 р. № 1135-IX. Офіційний вісник Украӥни. 2021. № 31. Ст. 1762.

11. Руссо Ж.-ЖЖ. Объ общественном договоре или начала политического права. Москва : Труд и воля, $1906.208 \mathrm{c}$

12. Философия власти / под ред. В. Ильина. Москва : Издательство Московского университета, 1993. 271 с.

13. Монтескье Ш.-Л. О духе законов. Монтескье Ш.-Л. Избранные произведения. Москва : Госполитиздат, 1955. С. 159-734.

14. Опришко В. Основні положення проєкту Концепції розвитку законодавства України до 2005 р. Пра во України. 1996. № 7. С. 3-10.

15. Назаренко Є. Запровадження в життя Конституції - головна мета сучасного етапу правової реформи державної влади. Конституиія України основа подальшого розвитку законодавства. Київ, 1997. Вип. 2. С. 36-44.

16. Заєць А. Вдосконалення структури законодавства як наукова проблема. Концепція розвитку законодавства України : матеріали наук.-практ. конф., травень, 1996 р. Київ, 1996. С. 55-57.

17. Шаповал В. Основний Закон України та актуальні проблеми конституційної теорії. Українське пра во. 1996. № 3. С. 13-21.

18. Рішення Конституційного Суду України у справі № 18/183-97 за конституційним зверненням Барабаша Олександра Леонідовича щодо офіційного тлумачення ч. 5 ст. 94 та ст. 160 Конституції України (справа про набуття чинності Конституцією України) від 3 жовтня 1997 р. № 4-зп. Вісник Конституиійного Суду України. 1997. № 2. С. 27-30.

19. Марцеляк О. Роль науки конституційного права в конституціоналізації правової системи України. Право України. 2016. № 6. С. 79-87.

20. Конституционное (государственное) право зарубежных стран : учебник. В 4 т. / отв. ред. Б. Страшун. Москва : БЕК, 1996. Т. 1-2. 778 с.

21. Тихомиров Ю. Теория закона. Москва : Наука, $1982.256 \mathrm{c}$.

22. Васильченко О. Класифікація законів як джерел конституційного права України. Кониепиія роз витку законодавства України : матеріали наук.-практ. конф., травень 1996 р. Київ, 1996. С. 142-143.

23. Проєкт Закону України «Про нормативні правові акти». Вісник Академії правових наук України. Харків, 1995. № 4. С. 141-163.
24. Конституція Литовської Республіки. Конституції нових держав Європи та Азії / упоряд. С. Головатий. Київ : Право, 1996. 544 с.

\section{Анотація}

Проиюк I. В. Класифікація законів: загальнотеоретичні аспекти. - Стаття.

Стаття присвячена дослідженню системи законодавчих актів і визначенню основних критеріїв поділу законів на групи (види), розглянуто головні критерії виокремлення законів у системі законодавчих актів, проаналізовано юридичну природу, значення, силу, призначення та їх особливості, запропоновано підходи до розподілу законів на види та нормативного закріплення такої класифікації.

Поділ законів на види у статті розглянуто за низкою критеріїв, які залежать від типу правової сім’ї і специфіки національних правових систем, а саме за: а) низкою питань, що регулюються законом; б) юридичною силою; в) структурною формою; г) простором, в межах якого вони діють; г) термінами їх дії; д) способом розгляду й ухвалення; е) цільовим призначенням і змістом; є) колом осіб, на яких вони поширюють свою дію; ж) часом набрання чинності тощо. Автор зазначає, що цей перелік не є вичерпним.

Особливу увагу в статті приділено виокремленню законів за ступенем узагальнення регулювання суспільних відносин і за структурним способом організації нормативного матеріалу 3 виділенням 3 усіх законів простих тематичних законів і кодифікованих (основ законодавства і кодексів). Кодекс - це системоутворювальний законодавчий акт, що регулює певну сферу суспільних відносин, навколо якого формуються інші законодавчі та підзаконні акти, що є відповідною сферою законодавства.

За дією у просторі виокремлюють ті закони, що діють на території всієї держави, та ті, що діють лише на визначеній частині території, за терміном дії- постійні і тимчасові, за цільовим призначенням і змістом - інституційні, регламентаційні та проблемно-ситуаційні.

Автор акцентує особливу увагу на такому критерії, як спосіб розгляду і прийняття законів, та виокремлює закони, прийняті на референдумі та прийняті парламентом. Звернено увагу на те, що думка про беззаперечні переваги референдуму послідовно не обгрунтована і референдум також певні недоліки.

Найбільш важливим і значущим критерієм поділу законів на види, на думку автора, є їх юридична сила. Згідно з цим критерієм виділено такі закони, як конституції, конституційні закони, звичайні закони та закони, що затверджують інші нормативні акти.

Автор зазначає необхідність ухвалення спеціального Закону «Про нормативно-правові акти», що має позитивно вплинути на юридичну практику, вирішити багато дискусійних питань юридичної науки щодо класифікації законів та їх взаємозалежності та співвідношення між собою.

Ключові слова: закон, система законодавчих актів, види законів, юридична сила, конституція, конституційний закон.

\section{Summary}

Protsiuk I. V. Classification of laws: general theoretical aspects. - Article.

The article is devoted to the study of the system of legislative acts and the definition of the main criteria for the division of laws into groups (types), the main 
criteria for distinguishing individual laws in the system of legislative acts are considered, the legal nature, meaning, force, purpose and their features are analyzed and the main approaches to the division of laws into types and normative consolidation of such classification are proposed.

The division of laws into types in the article is considered according to a range of criteria that depend on the type of legal family and the specifics of national legal systems, namely: a) the range of issues regulated by law; b) by legal force; c) structural form; d) the space within which they operate; e) the terms of its validity; g) method of consideration and acceptance; g) purpose and content; h) the circle of persons to whom they extend their action; i) the time of entry into force, etc. The author notes that this list is not exhaustive.

The article pays special attention to the separation of laws according to the degree of generalization of regulation of public relations and the structural way of organizing normative material with the selection of simple thematic laws and codified laws (basics of legislation and codes). The Code is defined as a systemcreating legislative act that regulates a certain area of public relations, around which other laws and regulations are formed, which are the relevant area of legislation.
According to the action in space, there are laws that apply throughout the state or only part of it, according to the term - permanent and temporary, according to the purpose and content - institutional, regulatory and problem-situational.

The author pays special attention to such criteria as the way of consideration and adoption of laws and singles out the laws adopted in a referendum and adopted by parliament. Attention is drawn to the fact that the opinion about the undeniable advantages of the referendum is consistently unfounded and the referendum also has certain shortcomings.

The most important and significant criterion for dividing laws into types, according to the author, is their legal force. According to this criterion, such laws as constitutions, constitutional laws, ordinary laws and laws approving other normative acts are distinguished.

The author notes the need to adopt a special law "On regulations", which should have a positive impact on legal practice, to solve many debatable issues of legal science regarding the classification of laws and their interdependence and correlation between them.

Key words: law, system of legislative acts, types of laws, legal force, constitution, constitutional law. 